\title{
Finding Common Ground in Collaborative Environmental Management: A Case Study in Cijedil Forest Landscape, Cianjur
}

\author{
Agung Hasan Lukman ${ }^{1 *}$, Budhi Gunawan²,3, Parikesit ${ }^{2,4}$ \\ ${ }^{1}$ Department of Forestry, Faculty of Agriculture, Universitas Bengkulu, Indonesia \\ ${ }^{2}$ Center for Environment and Sustainability Science, Universitas Padjadjaran, Indonesia \\ ${ }^{3}$ Department of Anthropology, Faculty of Social and Political Science, Universitas Padjadjaran, Indonesia \\ ${ }^{4}$ Department of Biology, Faculty of Mathematics and Natural Science, Universitas Padjadjaran, Indonesia
}

\begin{abstract}
Forest landscape in Cijedil Village, Cianjur hosts numerous endemic wildlife to conserve. On the other hand, the needs of local people from forest utilization could not be also neglected. Hence, the environmental management issues in the forest landscape of Cijedil are not only attributed to the biodiversity and ecological protection but also social and economic empowerment that engages various stakeholders. To get a mutual understanding among the stakeholders within collaborative management, building dialogue, reaching consensus, and comprehending its process is necessary. Nevertheless, few studies, particularly in Indonesia, have thoroughly performed related to this topic. The objective of this study is to fill this gap by describing the consensus building in the collaborative process framework and its affecting factors for reaching an agreement in collaborative management in the forest landscape of Cijedil. We performed a qualitative study by using action-based research and a case-study approach. Semi-structured and in-depth interviews were undertaken with 18 key informants selected by the snowball sampling representing six stakeholders involved: KPH Cianjur, SPH II Cianjur, BLHD Cianjur, officials of Cijedil Village, LMDH Cijedil, and the local community of Cijedil. The findings show that this consensus building has adapted the collaborative framework indicated by problem- and direction-setting activities in the first two stages of the collaborative process. It also suggests that the main influencing of parties-related factors are human resource capacity, level of understanding, and commitment, whereas processrelated barriers are time uncertainty and incentives offered. These factors are indicated not completely discrete but rather affecting each other. To conclude, while the consensus for broadly collaborative environmental management is still needed to promote, the driven inhibiting factors remain. It is, therefore, crucial to address and deal with those main challenging elements.
\end{abstract}

Keywords: Consensus building, Stakeholders, Collaborative process, Environmental management, Forest landscape

\begin{abstract}
Abstrak
Lanskap hutan di Desa Cijedil, Cianjur mempunyai banyak satwa endemik yang penting untuk dilestarikan. Namun di sisi lain, kebutuhan masyarakat lokal dari pemanfaatan hutan juga tidak bisa diabaikan. Oleh karena itu, masalah pengelolaan lingkungan di lanskap hutan Cijedil tidak hanya terkait dengan perlindungan keanekaragaman hayati tetapi juga pemberdayaan sosial dan ekonomi yang melibatkan berbagai pemangku kepentingan. Untuk mendapatkan pemahaman bersama di antara para pemangku kepentingan dalam pengelolaan kolaboratif, perlu membangun dialog, mencapai konsensus, dan memahami prosesnya. Namun demikian, baru sedikit penelitian, khususnya di Indonesia, yang telah dilakukan terkait topik ini. Tujuan dari studi ini adalah untuk mengisi kesenjangan ini dengan menggambarkan pembangunan konsensus dalam kerangka proses kolaboratif dan faktorfaktor yang mempengaruhinya untuk mencapai konsensus dalam pengelolaan kolaboratif di lanskap hutan Cijedil. Penelitian ini merupakan penelitian kualitatif berbasis aksi dan pendekatan studi kasus. Wawancara semi terstruktur dan mendalam dilakukan dengan teknik snowball terhadap informan kunci yang mewakili enam pemangku kepentingan yang terlibat: KPH Cianjur, SPH II Cianjur, BLHD Cianjur, aparat Desa Cijedil, LMDH Cijedil, dan masyarakat Cijedil. Temuan menunjukkan bahwa pembangunan konsensus ini telah mengadaptasi kerangka kerja kolaboratif yang ditunjukkan oleh aktivitas penetapan masalah dan arah dalam dua tahap pertama proses kolaboratif. Temuan juga menunjukkan bahwa faktor utama yang mempengaruhi terkait pihak adalah kapasitas sumber daya manusia, tingkat pemahaman, dan komitmen, sedangkan hambatan terkait proses adalah ketidakpastian waktu dan insentif yang ditawarkan. Faktor-faktor ini tidak sepenuhnya terpisah melainkan saling mempengaruhi. Penelitian ini menyimpulkan bahwa walaupun konsensus untuk pengelolaan lingkungan kolaboratif secara luas masih diperlukan, faktor-faktor penghambatnya masih tetap ada. Oleh karena itu, penting untuk mengatasi tantangan utama tersebut.
\end{abstract}

Kata kunci: Consensus building, Stakeholder, Proses kolaboratif, Pengelolaan lingkungan, Lanskap hutan

Citation: Lukman, A.H., Gunawan, B., and Parikesit. (2021). Finding Common Ground in Collaborative Environmental Management: A Case Study in Cijedil Forest Landscape, Cianjur. Jurnal Ilmu Lingkungan, 19(2), 399-408, doi:10.14710/jil.19.2.399-408

* corresponding author: ahaslukman@unib.ac.id 


\section{Introduction}

The forest landscape in Cijedil Village of Cianjur is subject to a high level of biodiversity and plays a key role in ecological functions despite not belong to conservation and protected forest (Muhamad et al., 2013). Numerous endemic and protected wildlife listed in the Government Act No. 7/1997 and Decree of Ministry of Environment and Forestry No. P.106/2018 inhabit this area, e.g., Javan gibbon (Hylobates moloch), Javan leopard (Panthera pardus), Javan hawk-eagle (Nisaetus bartelsi), Javan slow loris (Nycticebous javanicus), Javan leaf-monkey (Presbytis comata), and leopard cat (Felis bengalensis). Moreover, the ecological processes at the landscape level deliver various ecosystem services to local people, particularly for Pameungpeuk's residents, the nearest hamlet to the forest (Muhamad et al., 2014). Thus, it should be maintained to ensure the sustainability of the functions and services that have been provided.

Nevertheless, natural resource extraction in the forest, such as poaching, encroachment, and illegal logging continues to exist. These pose a serious threat to the entity and function of this landscape. Furthermore, the livelihood of surrounding communities who rely on forest products also drives these activities to be carried out (Muhamad et al., 2014). Hence, comprehensive and collaborative management that views the forest and communities as a holistic unit is needed to enhance environmental management (Gunawan et al., 2004; Sukwika et al., 2020).

Collaborative ideas concerning these issues urge that involving various parties is necessary (Reed, 2008; Fisher et al., 2017). Those who have an interest in the forest landscape of Cijedil are not only the local communities but also the forest managers, i.e., the Forest Management Unit (Kesatuan Pemangkuan Hutan, or KPH) Cianjur as the core stakeholders and other relevant parties. Through collaborative management, the parties could prioritize the achievement of common benefit goals instead of prioritizing their respective interests to ensure a better outcome (Scott, 2015).

However, developing collaborative management requires agreement among stakeholders (Wondolleck \& Yaffe, 2000; Gray \& Purdy, 2018). Consensus building could bridge the parties to find a mutual benefit for collaborative environmental management (Margerum \& Robinson, 2016). Therefore, the congruence of this study with the collaborative framework could explain how this consensus building process was undertaken. While several models and frameworks have been arising as noted by Lewins (2001) and Margerum (2016), the collaborative process proposed by Gray (1989) and Gray \& Purdy (2018) remains emerged as one of the generic frameworks of the collaborative management process for its suitability in various case studies of environmental and natural resources management.
Furthermore, major themes challenges in the consensus process would be a handicap if not carefully addressed, such as societal context, policy setting, power, collaborative capacity, participant factors, and costs and benefits as it could determine the success of the consensus building (Margerum, 2016; Gray \& Purdy, 2018). As few studies, particularly in Indonesia, have thoroughly performed related to this topic, this study shed light on this consensus building process and its influencing factors to enrich the practical experience and to enhance collaborative environmental and forest management that shares similar socio-ecological traits.

\section{Methods}

\subsection{Study site}

The study was undertaken in the forest landscape under the administration of KPH Cianjur and Cijedil Village, Cugenang District, Cianjur. This village is located about $7 \mathrm{~km}$ away from the City of Cianjur. It is divided into three dusun (neighborhood) and seven kampung (hamlets) in which Pameungpeuk is the nearest hamlet to the forest boundary (Figure 1). In the upland, remnant natural forest and tree plantation remain to exist managed by KPH Cianjur. Meanwhile, agricultural lands mainly owned by the community are rice fields and agroforest locally known as talun or kebon tatangkalan (Parikesit et al., 2005), consisting of bamboo, albizzia, and mix tree talun in the lower parts. Most residents earn living by farming and raising livestock although some of them step into the forest for once-a-week traditional wild boar game hunting, collecting fuelwoods, medicinal plants, honey, and wildlife poaching (Muhamad et al., 2014).

\subsection{Research design and data collection}

We performed action-based research and a casestudy approach in this qualitative study (Creswell \& Poth, 2017; Yin, 2018). The collaborative process framework developed by Gray (1989) was adapted to describe consensus building as a process since her recent work (Gray \& Purdy, 2018) does not thoroughly cover this topic while the negative factors of consensus for collaboration were drawn mainly from Margerum (2002, 2016) and Gray \& Purdy (2018) to identify its significant barriers (Figure 2). The collaborative framework is comprised of three general stages; a) problem-setting, b) direction-setting, and c) implementation. Since this study focused on describing the process, the implementation phase was excluded. The inhibitor aspects were categorized into partiesand process-related modified from Poitras et al. (2003). The primary data obtained through participatory observation during the consensus process and in-depth interviews with the key informants while secondary data collected simultaneously by reviewing relevant reports, materials, and other documentation related to this study. 


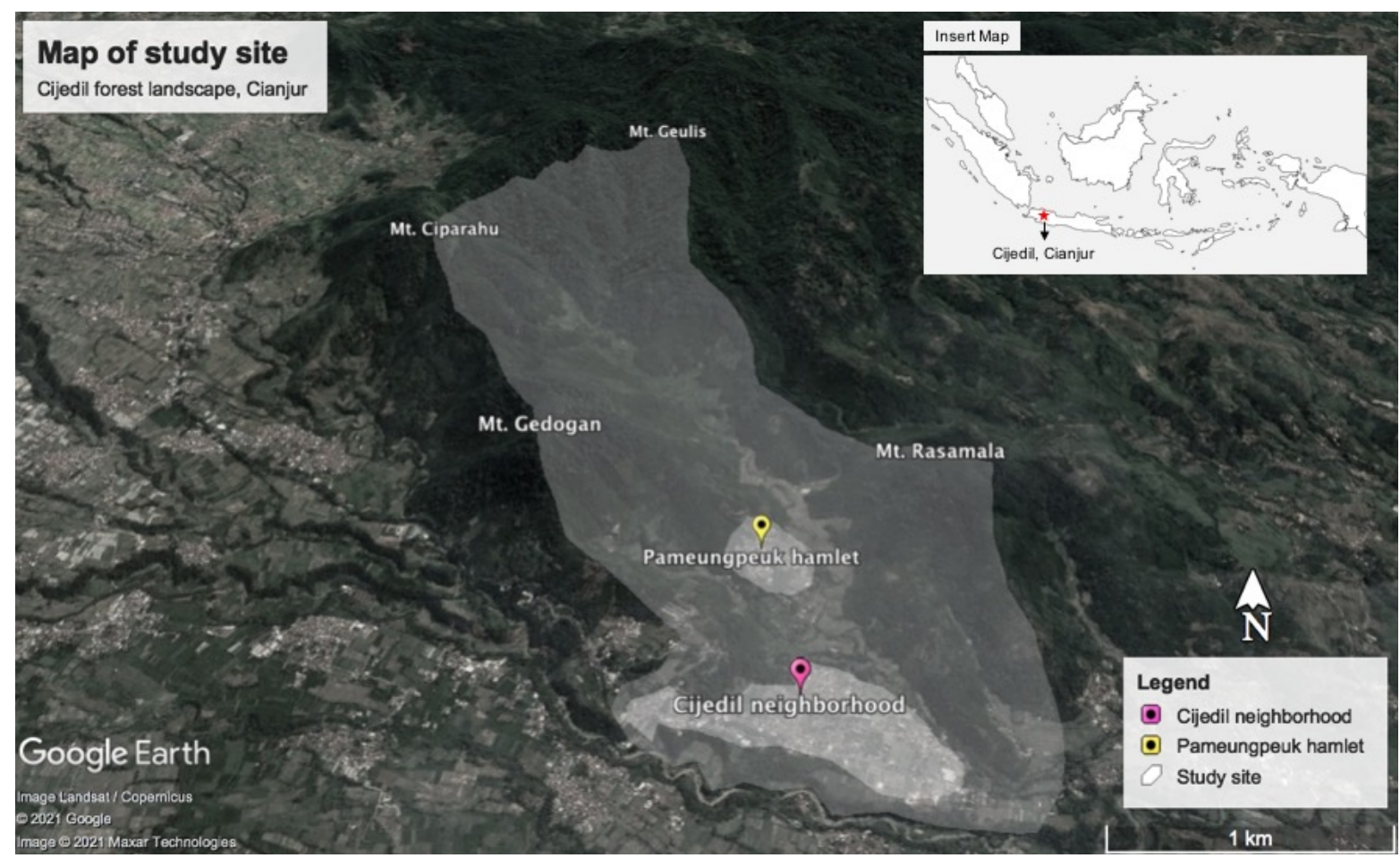

Figure 1. Map of study site in Cijedil forest landscape, Cianjur

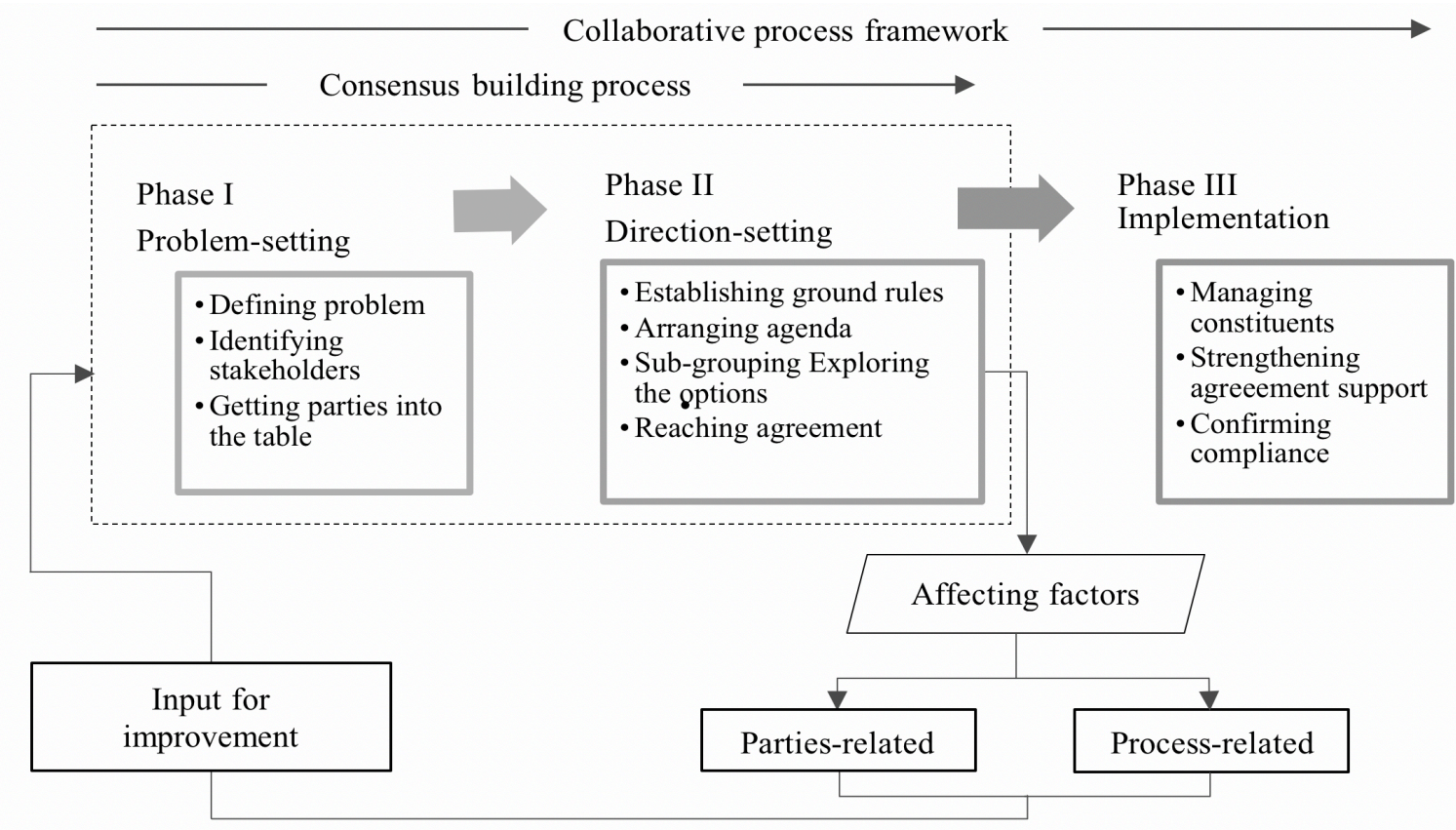

Figure 2. Consensus building within the collaborative process framework and its affecting factors adapted from Gray (1989), Margerum (2016), Gray \& Purdy (2018)

In-depth interviews using semi-structured guidelines were conducted with 18 key informants selected by the snowball sampling technique representing six stakeholders involved, i.e., KPH Cianjur, Division of Forest Planning II (Seksi Perencanaan Hutan II, or SPH II) Cianjur,
Environmental Agency (Badan Lingkungan Hidup Daerah, or BLHD) Cianjur, Forest Village Community Association of Cijedil (Lembaga Masyarakat Desa Hutan, or LMDH Cijedil), officials of Cijedil Village, and local community of Cijedil. 


\subsection{Data analysis}

The unit of analysis of this study is the consensus process within the collaborative process framework and its affecting factors. This study applied descriptive analysis by using interactive model analysis techniques (Miles et al., 2018). It consists of three concurrent flows of activity in the cyclical process: a) data reduction, b) data display, and c) conclusion drawing/verification. Initially, the data were selected, grouped, and organized. It is then presented and interpreted at the same time to describe the pattern and make propositions. For data validation purposes, triangulation was applied by comparing information from key informants in each stakeholder. It also involved the view of the researcher through participatory observations. Data analysis was carried out continuously from the initial preparation of research to the report writing.

\section{Results and Discussion}

\subsection{Consensus building within the collaborative process framework}

The consensus building process in the forest landscape of Cijedil could be considered consistent with Gray's (1989) collaborative process framework in general. It is indicated by such activities in the framework stages including problem-setting and direction-setting as depicted in Figure 2. However, the key points within each stage may do not share absolute similarity with the framework since every case of the consensus building process has its unique contextual and different typology (Margerum, 2008, 2016).

\subsubsection{First stage: Problem-setting}

During this stage, several key activities were identified as an effort of defining the problem, building commitment, and identifying relevant stakeholders. In the initial discussion, the core stakeholders, i.e., KPH Cianjur, village officials, and residents of Cijedil Village discussed and defined the problems and common interests assisted by the initiator. They identified three main issues to be addressed: a) the need to conserve a high level of biodiversity and endemicity in the forest and to maintain ecological processes of the landscape to ensure sustainability, b) the direct benefit of forest such as biodiversity and forest resources utilization by local communities could not be completely prohibited, and c) the lack of partnership between the parties. Thus, they agreed that it is necessary to build collaborative environmental management that not only aiming for ecological and biodiversity conservation but also bioresource utilization for the economic benefits of the surrounding community by establishing joint commitment and action. Since this idea may not be reached if there are no dialogue forums among parties, the core stakeholders also admitted to building a common understanding through further meetings and discussions that could produce a mutual agreement.

This first step shows that the stakeholders gained a mutual understanding of the importance of collaborative management by examining and specifying the main problems. However, they also recognize the efforts and time needed to achieve such a better outcome. Nevertheless, the parties remain keen to commit to the participatory process of collaborative management. It confirms other studies such as Balest et al. (2016) who revealed that efforts and time-consuming in joint action could be outweighed by collaborative advantage such as gaining general perspectives through reviewing problems and delivering cross-sectoral processes. Fisher et al. (2017) also imply that the better stakeholders' understanding, the stronger willingness to establish collaborative action through consensus building. Furthermore, Butler et al. (2015) also add that collaborative management for the parties is not only how the parties can collaborate but also their willingness to do so. Therefore, instilling understanding within stakeholders is valuable in the early phase of consensus building.

Subsequently, the core members explored other relevant stakeholders who were considered capable of supporting the consensus process both strategically and practically. In the first meeting, it was numerous stakeholder options ranging from district to provincial agencies and councils. By inviting the closest stakeholders in level 2 one-by-one to the focus group discussions (FGDs), it was then narrowed down to the district scope for practical purposes considering that the issue had more local context rather than provincial or regional (Figure 3). Finally, the supporting stakeholders invited were Perhutani of Regional Division III of West Java and Banten (or Perhutani Divre III), SPH II Cianjur and BLHD Cianjur. In fact, in the next series of dialogues, Perhutani Divre III were not much involved because KPH Cianjur was viewed as sufficient to represent the forest manager for the given territory.

Regarding identifying and getting stakeholders into the table, it is clear that the core parties identified other relevant stakeholders through a bottom-up and snowballing approach. The core stakeholders inventoried other relevant stakeholders starting from the smaller group to those who have greater power. In addition, they also explored the choice of stakeholders who might be involved, then invited one by one to narrow down the initial options. It confirms the study by Colvin et al. (2016) who state that snowballing is one of several means of identifying stakeholders in environmental management. By iterative process throughout the consensus, each party encountered in the meeting also served as a key informant to identify other stakeholders in such issue. Furthermore, this kind of engagement also conforms to stakeholder engagement types argued by Reed et al. (2018). They suggest that one of the stakeholder involvements of 
which bottom-up approach could lead to the coproduction of understanding and knowledge and beneficial outcome. Hence, other relevant parties involved could have a meaningful impact on the collaborative environmental governance leading to better ecological outcomes (Scott, 2015; Margerum \& Robinson, 2016).

In addition, the core stakeholders also agreed to appoint a joint research team (or, JRT) consisting of elements from higher education, research institution, agencies, and non-governmental organizations as facilitators throughout the consensus process. Originally, this team only acted as an initiator to encourage collaborative management as Muhamad et al. $(2013,2014)$ studies' suggested. The thought behind this appointment was that the parties acknowledged that the JRT has several advantages, i.e., expertise and scientific capacity related to the existing issue, diverse members to seek the potential financial assistance needed for the consensus through various sources, and could be a mediator given their status as a neutral party. In fact, this team recommended KPH Cianjur to be the leading sector for the consensus considering the landscape is within their territory and their capacity in environmental management. Instead, they decided to determine the JRT as a facilitator for the above reasons.

Concerning this context, the local community may put the trust in JRT to arrange the meeting and to manage the agenda in the right way since they are convinced that the JRT had no conflict of interest. Moreover, according to villager interviewees, they do not expect high from Perhutani, i.e., KPH Cianjur given their fairly poor performance in managing the forest as they have seen them firsthand, such as routine monitoring and patrolling to prevent wildlife poaching and forest encroachment. On the other hand, from KPH Cianjur's lens, they are confident that they have capacity but lack human and financial resources and lack of time due to bureaucracy bound if they handle this issue. These situations reflect existing studies such as Lestari et al. (2015) and Fisher et al. (2017). Lestari et al. (2015) suggest that rural communities sense trust in higher value. Hence, they were reluctant to make Perhutani a facilitator given the above reason. Meanwhile, Fisher et al. (2017) state that the forest managers believed what they capable of as facilitator and mediators in collaborative management. However, since both parties have their lacks the abovementioned, the external actor as facilitator is needed to bridge the consensus process. Gray \& Purdy (2018) state that a neutral actor as a convener may be necessary if the dispute is severe. Nonetheless, although the issue in this consensus is not extreme, yet it requires an independent third party as convener and facilitator.

\subsubsection{Second stage: Direction-setting}

In this stage, there were no established ground rules that formally govern the consensus process and interaction between stakeholders. The majority of stakeholders considered it was not a necessity because the atmosphere that was wanted to be built in this consensus process to avoid intense and rigidity. Rather, they preferred the circumstance to be more relaxed and informal, thereby eliminating formality and timidness among stakeholders who participated in the dialogue serie. In contrast, several studies argue that setting ground rules are necessary.

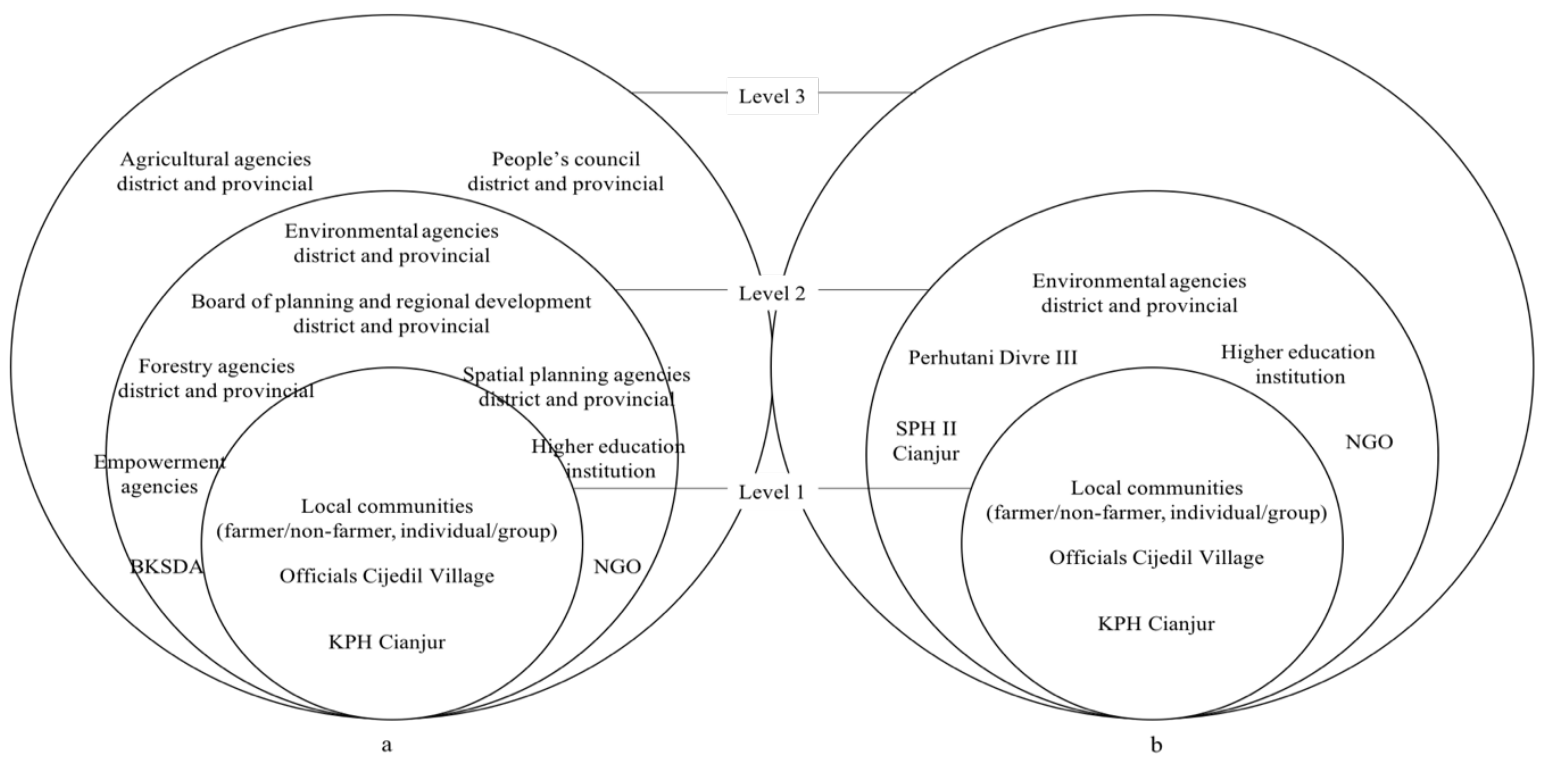

Figure 3. Identifying relevant stakeholders for consensus: (a) proposed stakeholders, (b) final stakeholders involved 
Innes (2004) suggests that failure to do so will likely damage the consensus in various kinds. Agranoff (2016) also notes that building ground rules would disarm network incompatibility and power disparities as barriers. This may be due to the parties involved are those who have large power which tends to have not more control. However, this consensus consists of local stakeholders who have limited power. Hence, they are more comfortable with no such rules.

The preparation of the agenda was originally designed by the facilitator who later disseminated it to the forum for feedback and agreed upon by all stakeholders. Meanwhile, the sub-group organizing was unnecessary since there were not too many stakeholders involved and a relatively homogenous background. It reflects the work of Gray \& Purdy (2018) who suggest that sub-group organization may be needed in a consensus process that has a large number of stakeholders and high in complexity to simplify issues through focus-group discussion to conduct consensus effectively.

The exploration of alternative solutions was carried out at each dialogue meeting. All the ideas considered as problem-resolving were conveyed by all stakeholders. It then incubated to sort them out which were substantive and realistic. The exploration of solution options was scoped out by the implementation of the Participatory Rural Appraisal (PRA) resulting in alternative programs as part of collaborative environmental management. The four program options included institutional strengthening, human resource capacity building, awareness and education on environmental conservation, and empowerment of alternative economic incomes. It was deemed acceptable to all parties. Thus, a final agreement was reached by signing the agreement letter (letter of intent) by all stakeholder representatives involved.

According to (Gray \& Purdy, 2018), the consensus agenda should be thoroughly set to guarantee that all parties' interests are considered as the dialogue commences. Moreover, the trade-offs and how the issues will be addressed are the next aspects that should be taken into account as the process continue. In this consensus, the four agreed programs are the result of narrowing down the process. Previously, the options were varied, such as changing the production forest to protective forest status and integrating local governmental's policy. However, they weigh out which options are more substantive and reachable in the foreseeable future. It then turns out that the four programs above-mentioned are considered more relevant and doable at grass root level than others.

\subsection{The affecting factors of the consensus process}

\subsubsection{Parties-related aspect}

The main factors from stakeholders' view showed relative similarities to the already existing studies. Innes (2004) and Margerum (2016) argued that human and financial resources are the main obstacle factors in consensus building (Table 1). It reinforces the findings based on the interview results that the majority of stakeholders perceived that these factors were vital in the implementation of the consensus building process that has been passed through.

Furthermore, according to Margerum (2002), the availability of budget resources is important for financing the consensus process, e.g. involving stakeholders, facilitation, and consultations expense. Hence, if the budget is tight or even not available, the consensus success rate may be low. However, in this study, the chances of a success rate are still relatively high even with limited financial support. It was emphasized by the responses of informants who stated that financial need is important but could still be discussed later during the dialogue series once a common vision has been reached in the initial meeting.

In contrast, the stakeholders amplified the availability of competent human resources particularly the facilitator as the prominent factor that could influence consensus building. An incompetent facilitator will lead to unclear consensus processes (Gray \& Purdy, 2018). Thus, the facilitator could highly influence the consensus process (Margerum, 2016). It was also reflected by this study as the facilitator not only designed, managed, directed the meetings and discussion but also educated the stakeholders to improve their understanding and commitment to the consensus process.

With regard to the facilitator role, the stakeholders were aware that such specific tasks could not be carried out by themselves. They argued that the facilitator consisting of members beyond the participants' affiliation could lead the meaningful course of consensus given their capacity and independence. However, the underlying arguments were slightly different, particularly between the core parties. While the community members expressed that a competent and independent facilitator could bring a good atmosphere and direct the dialogue on track, the KPH Cianjur members think that although the problem issue may be their expertise area but caught by bureaucratic daily workload. Hence, they felt that it was their disadvantage in terms of focus and time if taking a role as a facilitator. In sum, the stakeholders expressed that the consensus process still could be undertaken without the involvement of outsiders, either acting as a facilitator, mediator, or even initiator. However, the constraints and limitations of stakeholders in carrying out this role could cost the process. Thus, the existence and involvement of competent independent parties become a major necessity (Mohammed et al., 2017)

Moreover, Margerum (2016) mentioned that good understanding could provide a broader perspective on the issues being discussed while commitment shows the goodwill of each stakeholder in undergoing the consensus process. Interestingly, understanding and 
commitment were not prompted and embedded straight away in the initial discussion of a consensus process given the stakeholders were still not familiar with the themes in the matter being discussed. It was observed in the initial discussions, particularly with the community who had limited knowledge about collaborative environmental management as the theme of the discussion. As the meetings progressed, the education as part of social learning instilled by the facilitator was able to gradually enhance knowledge and understanding which in turn generated their awareness committing to participate in collaborative forest management (Wulandari \& Inoue, 2018).

Meanwhile, the historical relationship and institutional culture were not considered as significant barriers to the consensus. The stakeholders reckoned that the lack of good interactions as part of the historical relationship could not hamper the consensus. On the contrary, Margerum (2016) argues that historical relations and institutional culture could be an obstacle in achieving a successful consensus. While Gray \& Purdy (2018) state that the dispute among stakeholders resulted from historical institutional legacy could create problems and make the consensus process difficult, the parties believed that it only required reconciliation and adaptation to the initial dialogues. Once understanding and commitment grew to recognize the greater common interest, it could be resolved afterward.

Regarding the institutional culture aspect, Margerum (2016) suggests that it could be a negative factor in a consensus building process. The political culture of the institution which tends to have a shortterm view, bound to the fiscal year activities, institution rigidity, not get used to collaborative practices, battle of collaborative and core business, and network legitimacy and formal acknowledgment are referred to elements that hinder the consensus process (Margerum, 2016). However, according to the stakeholders, those were not major obstacles. They argued that almost every institution or community has its unique traditions and ways of working culture. The stakeholders' contrasting opinions with Margerum (2016) are similar to the aforementioned thought that as long as they understand the common interests of the consensus process and are committed to its implementation, it could be resolved.

Based on the above explanation, it could be seen that the human resource factor is more dominant than other factors in influencing the consensus process from an institutional aspect view. While various studies such as Innes (2004) and Margerum (2002) revealed that the consensus process is difficult to achieve if the financial resources are limited, this study indicated that consensus building is difficult to reach a final agreement if human resources, particularly the facilitators, are weak and incompetent.

However, it is also noteworthy that these factors are not discrete but affected each other. For example, competent human resource factors, the facilitator's role, in particular, could influence the understanding and commitment of the stakeholders involved so that it could convince them to remain present at the dialogue table and reach a mutual final agreement. Furthermore, it could also influence the sustainability of the consensus process even though its implementation is constrained by financial resources. Facilitators and stakeholders who think that financial needs are not a top priority could convince other stakeholders to remain present to continue the consensus process and reach a final agreement.

\subsubsection{Process-related aspect}

Uncertainty and incentives emerged as the main obstacles in the process-related aspect (Table 1). The stakeholders viewed that uncertainty, both time and outcome, was the main factor influencing the consensus building process. Similarly, Coglianese (1999) and (Margerum, 2016) also noted that the consensus process demands too much time, effort, and financial resulting in uncertainty over time and results.

Table 1. The affecting factors of consensus building process in Cijedil forest landscape, Cianjur

\begin{tabular}{|c|c|c|c|c|c|c|c|c|c|c|c|c|}
\hline \multirow{2}{*}{ No } & \multirow{2}{*}{ Key informants } & \multicolumn{5}{|c|}{ Parties-related* } & \multicolumn{5}{|c|}{ Process-related ${ }^{* *}$} & \multirow{2}{*}{$n$} \\
\hline & & Und. & Com. & Res. & His. & Cul. & Sel. & Inc. & Unc. & Anx. & Tec. & \\
\hline 1 & KPH Cianjur & & & & & & & & & & & 4 \\
\hline 2 & SPH II Cianjur & & & & & & & & & & & 2 \\
\hline 3 & LMDH Cijedil & & & & & & & & & & & 2 \\
\hline 4 & BLHD Cianjur & & & & & & & & & & & 1 \\
\hline 5 & $\begin{array}{l}\text { Officials of Cijedil } \\
\text { Village }\end{array}$ & & & & & & & & & & & 2 \\
\hline 6 & $\begin{array}{l}\text { Pameungpeuk } \\
\text { residents }\end{array}$ & & & & & & & & & & & 7 \\
\hline
\end{tabular}

Source: Primary data tabulation

*Und: Understanding, Com: Commitment, Res: Resources, His: Historical, Cul: Culture

**Sel: Selection and composition, Inc: Incentives, Unc: Uncertainty, Anx: Anxiety, Tec: Technical complexity Shading of important scale:
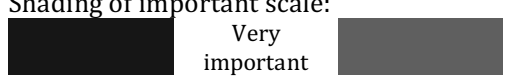

Important

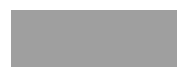


The uncertainty is considered could disrupt routine schedules and erode the interest and commitment of stakeholders present in the dialogue. With regard to incentive, the stakeholders strongly believed that it played a pivotal role in the consensus process. Interestingly, they put it into a phrase of "karaos sareng kahartos" (meaning: meaningful benefit and comprehensible) to emphasized its importance. It could be manifested as a monetary return for their presence and contribution to the consensus process and material benefit as the consensus reached, e.g., plants seed, infrastructure, or other aid programs. While these kinds of incentives were slightly different from Poitras et al. (2003) and (Margerum, 2016) who state that it is more expressed as immaterial such as institutional advantage and regulatory benefit, this study was also reciprocal with Djamhuri (2008) and Fujiwara et al. (2012) who reveal that financial opportunity could enhance collaborative forest management. Furthermore, the aforementioned participants' phrase could also be a financial hint since it implies economic terms rather than immaterial incentives. Nonetheless, aside from the different types of those benefits, the lack of incentive to find compromise could discourage the involvement of stakeholders in the dialogue (Akamani et al., 2015; Hossu et al., 2018).

Regarding anxiety and selection-composition, only a few stakeholders thought that it was considered as the main factor that could slow down the consensus process (Table 1). It was quite surprising as previous studies suggested that those are the main factors to interfere with the consensus process by the majority of stakeholders. In terms of anxiety, Margerum (2002, 2016) implies that every stakeholder is mostly concerned about the parochialism in consensus that could disrupt the process. Besides, Poitras et al. (2003) argue that anxiety is related to hidden agendas brought by each party, and, thus, creating fear of being exploited by other stakeholders and mistrust among members during consensus (Gray \& Purdy, 2018).

These contrasting results may relate to the communication pattern among each stakeholder. In this study, communication among parties has been built by engaging core stakeholders through bioecological research (Muhamad et al., 2013, 2014) long before the idea of consensus was ignited. This indirectly becomes an investment in cultivating trust to prevent negative prejudices among parties during the consensus. It confirmed studies performed by Witasari (2016) and Lee et al. (2017) who also assert that trust establishes mutual support for collective action in forest management. Conversely, it may be indicated that the stakeholders' communication in some of consensus projects of previous works such as Margerum (2002) and Poitras et al. (2003) is abruptly started in the initial dialogues led to the lack of trust among parties during the process. In some cases, it causes lengthy discourse even needed extensive time to identify, define, and agree upon a common problem at the first stage of the consensus. Hence, it could be implied that trust-building by engaging and communicating with the stakeholders prior to the consensus process is crucial.

Concerning selection-composition, the stakeholders stated that it was not a big issue since the forum could mutually agree on which parties need to be involved in the beginning discussion. In contrast, Innes (2004) and Margerum (2016) argue that it is also important in relation to the need of determining the limit on the number of stakeholders. In this study, the stakeholders' involvement in deciding the invited parties through a focus group discussion series may contribute to their opinions regarding this matter. Hence, they were convinced that the participants in the dialogue were relevant stakeholders and not perceiving it as a major problem. However, they also mentioned that it may be different if the selection had already been determined without their consideration since they need clarity on why such parties being involved. Therefore, it confirms previous studies that the inclusive approach and stakeholders' self-selecting inclusion through the iterative process are the key to selecting relevant stakeholders as it is impossible to get all the parties into the table (Reed, 2008; Colvin et al., 2016).

With regard to technical complexity, the stakeholders considered that it also was not a substantial factor. However, some authors such as (Gray \& Purdy, 2018) note that it could cause difficulties in dialogue. In fact, it is a common nature in such cases and every consensus process involved technical complexity (Margerum, 2002, 2016). Thus, the stakeholders viewed that it could not hamper the consensus process.

Based on the findings described above, this study suggests that many different factors influence a consensus building process. In other words, none of the consensus building processes are influenced exactly by the same factors considered to be impacted in previous cases. In one example, such a factor may be considered to greatly influence the discussion by stakeholders. However, in other cases, this factor may not be considered the main problem. Margerum (2016) and Gray \& Purdy (2018) provide meticulous discussion regarding these influencing factors. Therefore, understanding the socio-ecological characteristics of involved stakeholders is one of the keys to conducting consensus building effectively to mitigate the negative factors.

\section{Conclusion}

Overall, consensus building in this study showed congruence with the collaborative process framework divided into stages of determining problems and setting direction although not all activity components in the framework's stages were adopted. The main 
factors that influence the consensus process from the parties-related aspect are the availability of human resources, including independent and competent facilitators, understanding, and commitment while uncertainty and incentives were viewed as the main obstacles in terms of process-related factors.

Capacity building of human resources, establishing communication among stakeholders, sticking to the timeline for consensus building, and offering fair incentive mechanisms are strongly recommended prior to implementing consensus building. This study also suggested the need to examine the consensus process in other collaborative initiatives to enrich scientific literature and practical experience and to promote consensus building in collaborative environmental management.

\section{Acknowledgment}

We extend our sincere gratitude to all the stakeholders for their assistance during this study being undertaken.

\section{REFERENCES}

Agranoff, R. (2016). The other side of managing in networks. In R. D. Margerum \& C. J. Robinson (Eds.), The Challenges of Collaboration in Environmental Governance (pp. 81-107). Cheltenham: Edward Elgar Publishing.

Akamani, K., Wilson, P. I., \& Hall, T. E. (2015). Barriers to collaborative forest management and implications for building the resilience of forest-dependent communities in the Ashanti region of Ghana. Journal of Environmental Management, 151, 11-21. https://doi.org/10.1016/j.jenvman.2014.12.006

Balest, J., Hrib, M., Dobšinská, Z., \& Paletto, A. (2016). Analysis of the effective stakeholders' involvement in the development of National Forest Programmes in Europe. The International Forestry Review, 18(1), 1328. 10.1505/146554816818206122

Butler, W. H., Monroe, A., \& McCaffrey, S. (2015). Collaborative Implementation for Ecological Restoration on US Public Lands: Implications for Legal Context, Accountability, and Adaptive Management. Environmental Management, 55(3), 564-577.

Coglianese, C. (1999). The Limits of Consensus. Environmental Protection, 02138(April), 28-33.

Colvin, R. M., Witt, G. B., \& Lacey, J. (2016). Approaches to identifying stakeholders in environmental management: Insights from practitioners to go beyond the "usual suspects." Land Use Policy, 52, 266-276. https://doi.org/10.1016/j.landusepol.2015.12.032

Creswell, J. W., \& Poth, C. N. (2017). Qualitative Inquiry \& Research Design: Choosing Among Five Approaches (4th ed.). Thousand Oaks: SAGE Publications.

Djamhuri, T. L. (2008). Community participation in a social forestry program in Central Java, Indonesia: The effect of incentive structure and social capital. Agroforestry Systems, 74(1), 83-96.

Fisher, L. A., Kim, Y. S., Latifah, S., \& Makarom, M. (2017). Managing forest conflicts: Perspectives of Indonesia's forest management unit directors. Forest and Society, 1(1), 8-26. https://doi.org/10.24259/fs.v1i1.772

Fujiwara, T., Septiana, R. M., Awang, S. A., Widayanti, W. T.,
Bariatul, H., Hyakumura, K., \& Sato, N. (2012). Changes in local social economy and forest management through the introduction of collaborative forest management (PHBM), and the challenges it poses on equitable partnership: A case study of KPH Pemalang, Central Java, Indonesia. Tropics, 20(4), 115-134.

Gray, B. (1989). Collaborating: Finding Common Ground for Multiparty Problems. San Francisco: Jossey Bass.

Gray, B., \& Purdy, J. (2018). Collaborating for Our Future: Multistakeholder Partnerships for Solving Complex Problems. Oxford: Oxford University Press.

Gunawan, B., Takeuchi, K., Tsunekawa, A., \& Abdoellah, O. S. (2004). Community dependency on forest resources in West Java, Indonesia: The need to re-involve local people in forest management. Journal of Sustainable Forestry, 18(4), 29-46.

Hossu, C. A., Ioja, I. C., Susskind, L. E., Badiu, D. L., \& Hersperger, A. M. (2018). Factors driving collaboration in natural resource conflict management: Evidence from Romania. Ambio, 47(7), 816-830.

Innes, J. E. (2004). Consensus building: Clarifications for the critics. Planning Theory, 3(1), 5-20. https://doi.org/10.1177/1473095204042315

Lee, Y., Rianti, I. P., \& Park, M. S. (2017). Measuring social capital in Indonesian community forest management. Forest Science and Technology, 13(3), 133-141. https://doi.org/10.1080/21580103.2017.1355335

Lestari, S., Kotani, K., \& Kakinaka, M. (2015). Enhancing voluntary participation in community collaborative forest management: A case of Central Java, Indonesia. Journal of Environmental Management, 150, 299-309. https://doi.org/10.1016/j.jenvman.2014.10.009

Lewins, R. (2001). Consensus building and natural resource management: a review. CEMARE Research Paper 157, 48.

Margerum, R. D. (2002). Collaborative planning: Building consensus and building a distinct model for practice. Journal of Planning Education and Research, 21(3), 237-253. https://doi.org/10.1177/0739456X0202100302

Margerum, R. D. (2008). A typology of collaboration efforts in environmental management. Environmental Management, 41(4), 487-500.

Margerum, R. D. (2016). Theoretical perspectives on the challenges of collaboration. In R. D. Margerum \& C. J. Robinson (Eds.), The Challenges of Collaboration in Environmental Governance (pp. 27-53). Cheltenham: Edward Elgar Publishing.

Margerum, R. D., \& Robinson, C. J. (Eds.). (2016). The Challenges of Collaboration in Environmental Governance. Cheltenham: Edward Elgar Publishing.

Miles, M. B., Huberman, A. M., \& Saldaña, J. (2018). Qualitative data analysis: A methods sourcebook (4th ed.). Thousand Oaks: SAGE Publications.

Mohammed, A. J., Inoue, M., \& Shivakoti, G. (2017). Moving forward in collaborative forest management: Role of external actors for sustainable Forest socio-ecological systems. Forest Policy and Economics, 74, 13-19. https://doi.org/10.1016/j.forpol.2016.10.010

Muhamad, D., Okubo, S., Harashina, K., Parikesit, Gunawan, B., \& Takeuchi, K. (2014). Living close to forests enhances people's perception of ecosystem services in a forestagricultural landscape of West Java, Indonesia. Ecosystem Services, 8, 197-206. https://doi.org/10.1016/j.ecoser.2014.04.003

Muhamad, D., Okubo, S., Miyashita, T., Parikesit, \& Takeuchi, K. (2013). Effects of habitat type, vegetation structure, 
and proximity to forests on bird species richness in a forest-agricultural landscape of West Java, Indonesia. Agroforestry Systems, 87(6), 1247-1260. https://doi.org/10.1007/s10457-013-9633-x

Parikesit, Takeuchi, K., Tsunekawa, A., \& Abdoellah, O. S. (2005). Kebon tatangkalan: A disappearing agroforest in the Upper Citarum Watershed, West Java, Indonesia. Agroforestry Systems, 63(2), 171-182. https://doi.org/10.1007/s10457-004-1182-x

Poitras, J., Bowen, R., \& Wiggin, J. (2003). Challenges to the use of consensus building in integrated coastal management. Ocean and Coastal Management, 46(5), 391-405.

Reed, M. S. (2008). Stakeholder participation for environmental management: A literature review. Biological Conservation, 141(10), 2417-2431. https://doi.org/10.1016/j.biocon.2008.07.014

Reed, M. S., Vella, S., Challies, E., de Vente, J., Frewer, L., Hohenwallner-Ries, D., Huber, T., Neumann, R. K., Oughton, E. A., Sidoli del Ceno, J., \& van Delden, H. (2018). A theory of participation: what makes stakeholder and public engagement in environmental management work? Restoration Ecology, 26, S7-S17. https://doi.org/10.1111/rec.12541
Scott, T. (2015). Does collaboration make any difference? Linking collaborative governance to environmental outcomes. Journal of Policy Analysis and Management, 34(3), 537-566.

Sukwika, T., Yusuf, D. N., \& Suwandhi, I. (2020). The institutional of local community and stratification of land ownership in surrounding community forests in Bogor. Jurnal Manajemen Hutan Tropika, 26(1), 59-71. https://doi.org/10.7226/jtfm.26.1.59

Witasari, A. I. (2016). Trust building to coordinate collective action in reforestation program. Jurnal Manajemen Hutan Tropika, 22(3), 192-201.

Wondolleck, J. M., \& Yaffe, S. L. (2000). Making Collaboration Work: Lessons from Innovation in Natural Resource Management. Washington DC: Island Press.

Wulandari, C., \& Inoue, M. (2018). The Importance of Social Learning for the Development of Community Based Forest Management in Indonesia: The Case of Community Forestry in Lampung Province. Small-Scale Forestry, 17(3), 361-376.

Yin, R. K. (2018). Case study research and applications: Design and methods (6th ed.). Thousand Oaks: SAGE Publications. 